\title{
Transaction Costs: A Conceptual Framework
}

\author{
A. YousuF \\ University of Debrecen, Faculty of Economics and Business Administration, Department of Logistics, \\ allamyousuf@yahoo.com
}

Abstract. Transaction Costs (TC) is a very important topic, especially in a changing work environment which has a large number of operational firms, and increasing business growth. The aim of this paper is to shed light on the transaction costs concept, and provide a conceptual framework to understand the meaning of transaction costs. Publications including articles and research papers have explained the notion of transaction costs and the theoretical issues related to them. The literature review reveals that, transaction costs are costs which arise because of the of a company's activities in the market, including (fees, commission, taxes) which are paid by the firm to provide a service or produce a good either to external parties or as internal costs.Therefore, according to the literature review. It emerges that firms must make a comparison between internal and external transaction costs and choose the lowest cost which enables them to increase profits. This means companies have to reduce transaction costs to the minimum level to achieve more profits and competitive advantage.

\section{Introduction}

The changing work environment, th increasing growth of businesses and the complex regulatory environment in addition to the need to give special support to navigate complex global regulations especially for firms which are contemplating a move outside borders and becoming international, have all pushed companies to find ways to do their business either independently or to depend on other firms. All of this leads to the appearance of transaction costs (internal and external) which are consider an important topic of study. Transaction costs are concerned with finding and negotiating with a proper partner and monitoring the performance of this partner [1], because a potential partner might have an incentive to free ride or act opportunistically, and this presents the problem of monitoring performance.

The first analysis of transaction costs was made by Coase in his paper "The Nature of the Firm", which described them as simply "the cost of using the price mechanism" [2]. Coase used it to develop a conceptual framework to foresee when certain economic tasks would be done by firms, and when they would be performed on the market. In this attempt, Coase tried to explain what enables a firm to be number one in a market through a clarification of the differences between firms[2]. Subsequently, Williamson developed this framework and identified why costs arise when using the market [3]. The ownership decision in transaction costs is concerned with the minimization of costs in transactions and production [3]. Williamson's theory was founded on the decision made by the firm to make a good or service in the company or to get it from the market. Those activities define the vertical boundaries 
of the firm. Then Williamson proposed that the vertical boundaries of the firm are dependent on the transaction costs related to buying the good on the market [3]. Furthermore, when transaction costs are high, it is better for a company to produce the goods, by vertically integrating activities, rather than buying them on the market [3]. Therefore a firm will seek to expand until the price of doing a task within the firm is the same as that of buying them on the market - by making a transaction [3]. Then, Coase explained that the firm can get rid of costs which arise from using the market by depending on itself [4]. Following this, transaction costs became associated with Williamson as Williamson's transaction costs economics. Furthermore, Williamson was the first author who discussed the determinants of transaction costs. In terms of both terminology and content he is one of the strongest proponents of applying the notion of transaction costs. Subsequently, research and studies related to transaction costs by other researchers started to appear. Theses researchers explained that there are two perspectives surrounding the concept of transaction costs [5]. The first is property rights which focus on the role transaction costs in shaping the distribution of property rights [2]. The second is the 'neoclassical' literature on transaction costs, beginning in the early 1950s; this literature defines transaction costs more narrowly, and generally models them more explicitly, and often analyses them as identical to transportation charges or taxes. Other researchers clarified that the term transaction costs can itself instead be traced back to the monetary economics literature of the 1950s, and does not appear to have been consciously 'coined' by any particular individual [6].

\section{Literature Review}

Transaction costs theory may be one of the most important organizational theories because of the studies that have been encouraged through it [7], and it remains one of the main perspectives in organizational studies [8]. Moreover, transaction costs economics theory is frequently viewed as a subset of new institutional economics. The new trend in transaction costs is to describe firms from a new perspective based on organizational terms, as governance structures, not in neoclassical terms, as production functions [9]. Evidence has been found that the performance of firms which take into consideration transaction costs is better than the performance of firms which not consider them [10]. Furthermore, it was found that companies that follow the basic transaction costs hypothesis, (i.e. having high costs of finding and negotiating with partners), tend to use a higher degree of control [1]. In addition, transaction-costs economics has recognized that the productivity of a value chain is a function of both production costs and transaction costs, and that, moreover, transaction costs are significant and have a major impact on economic efficiency [11]. From a global sourcing perspective companies get their intermediate products from outside suppliers if the transaction costs of external purchases are lower than domestic ones. In other words, transaction costs determine the governance structure of a supply chain [12].

So, in the light of globalization, firms have to decide whether to follow a domestic or a global source to supply their needs. Furthermore, firms must consider the costs of negotiating and concluding contracts for each transaction [2]. Those costs cannot be eliminated, but the firm can reduce them by making one contract for a longer period instead of many shorter contacts. The firm is treated as an avoider of transaction costs, i.e. of negative costs [13]. Williamson refers to human actors as positive 
transaction costs and in pragmatic methodology all of them play key roles in the transaction costs treatment of inter firm contracting [14]. In addition, there are vertical integration consequences, i.e. the replacement of the costs of buying and selling on the market by the costs of intra-firm transfers; the existence of vertical integration may suggest that the costs of operating competitive markets are not zero [14]. The idea of zero transaction costs is a fiction [2]. Economic approaches to the study of organization and transaction costs focus on efficiency [14]. Therefore, the transaction costs approach is applied at three levels of analysis: firstly, the firm-wide level (this takes into consideration all operational activities which are related to each other), secondly, operational level, which determines activities will be done inside and outside the firm. Thirdly, human capital organizing approaches (creating harmony between interior structures and work groups).

Like other economic concepts, transaction costs have some factors which lead to their creation, which can be termed the antecedents of transaction costs. First, governance structures; according to economics literature [15], there are many governance structures which mediate the relations between companies, and the harmony between them leads to new structures. Another researcher has noted that production process include many stages and groups of activities [2], and a firm's boundaries was change according to the economic assessments made (i.e. when does the firm decide to integrate? when does it rely on the market?).

Secondly, organizational theory literature (dealing with internal organizational issues) conceives of the organization in terms of problem facing and problem solving, and takes into consideration both uncertainty and bounded rationality, and focus on the best way to economize on transaction costs[16]. Thirdly, there is the literature of contract law (i.e. contracts addressed as a governance issue).

\subsection{Types of transaction costs}

In general there are two main types of transaction costs, internal transaction costs and external one.

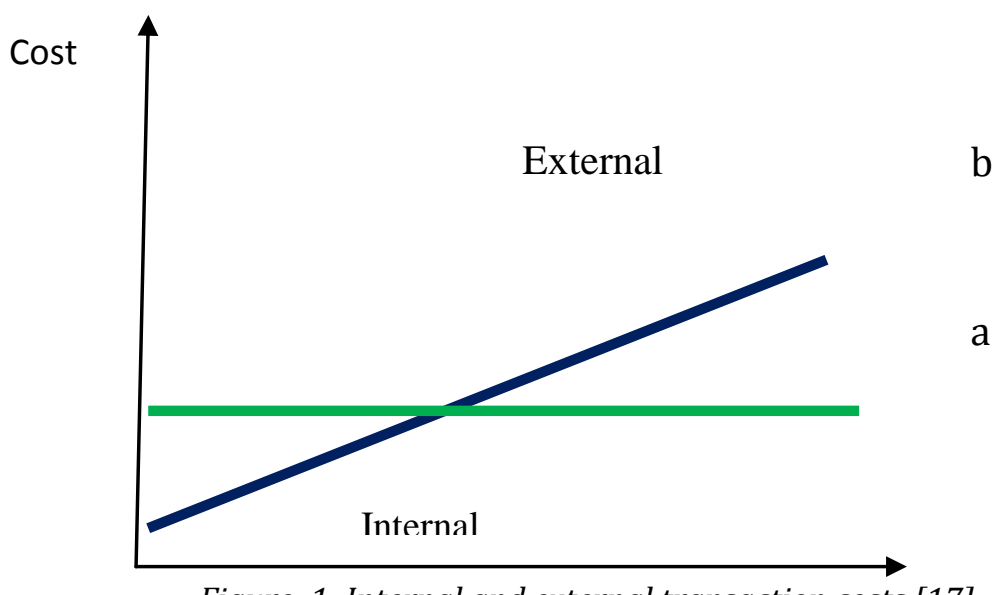

Figure: 1: Internal and external transaction costs [17] 
The horizontal line (a) is the cost of doing any transaction within a firm; essentially it is the fixed cost of overheads, so any in-firm transaction costs are in effect the same.

Coase argued that the firm will want to do all the work internally where line (a) is below line (b), as these costs are less. As expected, it tends to be the more complex transaction that the firm will carry out internally. When the external transaction costs are higher than the internal transaction costs, this will push company to grow, whereas when, the internal transaction costs are higher than the external transaction costs, the company will be downsized by outsourcing.

\subsection{Dimensions of transactions costs}

There are two main factors which lead to high transaction costs, human factors and environmental factors [3], Human factors include, firstly, opportunism: a term connected to "self seeking interest for guile" [18]. This refers to the benefits which the person (supplier) will get if the firm does not adopt safeguards. A firm must use safeguards as a guarantee when signing contracts to be sure that services agreed upon are fulfilled, and the supplier will not tend to act in his own best interest. So firms carry out internally transactions by vertical integration, to avoid the risks which arise from post-contractual opportunistic behavior [19]. Secondly, bounded rationality, which means there is not enough information [20], which enables designers to estimate decision alternatives because of limited capabilities regarding cognitive abilities and rationality, so transaction costs increase. The company cannot always easily make the right decisions because they do not have all information about a given relationship or environment [3]. There are also critical dimensions for describing transaction costs as environmental factors [21]. First, transaction specific assets; this refers to physical as well as human investments that are specialized for one or a few users and have less value outside the specific transactional relationship. Transaction specific assets are defined as investments specialized to one or a few users and can be both physical and human [22]. Asset specificity refers to the problem which occurs when the first element of transaction investments in human or physical capital, cannot be fully recovered if the transaction is completed. There are three reasons transaction costs can increase, which are[23]: a) site specificity; a series of stations are located closely to each other to reduce both inventory and transportation costs, b) physical assets specificity; where specialized machines are required to produce a component, and c) human assets specificity; these arise from learning by doing (experience costs). In the same domain transaction costs arise within firms for three reasons [19]. First, production resources belongs to different parties and they have an incentive to monitor the use of their assets; second, limitation people using information; thirdly, the need to monitor work intensity when there is no effort which is not directly tied to the reward system. Furthermore, there is uncertainty; uncertainty exacerbates the problems that arise because of bounded rationality and opportunism [24]. The presence of asset specificity market, uncertainties means that it is costly to monitor a partner and enforce contracts [25]. Uncertainty refers to any expected changes in the working environment of the firm, which affect on firm transactions, so adaptation is required to cope with these changes and the disturbances arising from transaction costs [14]. Another factor is frequency (small numbers trading); i.e. how many times those transactions recur. 


\subsection{Categories of transactions costs}

There are differences between internal transactions which are performed internally and those which are externally negotiated in the market. The theory of the firm consists of a number of economic theories that explain and predict the nature of the firm, company or corporation, including its existence, behavior, structure, and relationship to the market [26]. Firms sign a long-term contract with their employees or suppliers to minimize costs or maximize profits, because continuously changing suppliers is costly for companies [2].

Every company will expand as long as the company's activities can be performed cheaper within the company, than by, for example, outsourcing the activities to external providers in the market[2], where as transaction costs occur when a good or a service is transferred across to a separate interface[23]. In general, transaction costs arise when a product or service is transferred from stage to stage, and when new sets of technological capabilities are needed to produce a product or service. There are two models of transactions costs, the transaction costs of using the market and those of using the firm [19]. We can distinguish two major categories of transaction costs, firstly, Alston and Gillespie's approach to transaction costs, in which the best understanding of transaction costs is gained by recognizing the differences between types of transaction costs which occur through various production stages,[19]. According to the opinion of Alston and Gillespie, transaction costs fall into two groups: firstly, production factors (physical and finance capital, human capital and work intensity). Secondly, the production process (pre-production, production and post production) [19], and this view is supported by Williamson's approach in which he continually emphasizes that contracts must be viewed in their entirety [3]. The following table illustrates the structure of transaction costs [19]:

\begin{tabular}{|c|c|c|c|}
\hline Factors of production & \multicolumn{2}{|l|}{ Production Process } \\
\cline { 2 - 3 } & Pre-production & Production & Post-production \\
\hline $\begin{array}{c}\text { Physical and financial } \\
\text { capital }\end{array}$ & Asset specialty & $\begin{array}{c}\text { Abuse and agency costs } \\
\text { Measurement of output } \\
\text { and contract } \\
\text { enforcement }\end{array}$ \\
\hline Human capital & $\begin{array}{c}\text { Information constraints } \\
\text { and asset specialty }\end{array}$ & Coordination costs & \\
\hline Work Intensity & & $\begin{array}{c}\text { Shirking and contract } \\
\text { enforcement }\end{array}$ & \\
\hline
\end{tabular}

Table 1: Structure of transaction costs [19]

The table above shows that (pre-production, post -production) factors are those which encourage the firm to produce, and in their absence it is better to rely on market transactions. "The items under 'production' are the costs of using the firm" [19], in which case there is no market transaction costs. We can observe that:

Firstly, production processes within the firm affect the transaction costs borne by the firm. Moreover, without production processes firms need to deal with other parties, which mean rising market transaction costs.

Secondly, transaction costs are a function of what factors an individual supplies to the production process. In general, there are three main categories of transaction costs [27], first; search and 
information costs: these costs appear, if a required product is available on the market, and has the lowest cost in terms of its price, relative utility and functionality, the potential service costs of using the product on an ongoing basis, and other related areas. This affects the rational behavior of consumers who will search for a better product or service until they get the best utility at the lowest price. Search costs are divided into external and internal costs [28].

External costs include the paid costs of getting the information, in addition to the opportunity cost of the time taken up in searching; whereas internal costs include the mental effort devoted to undertaking the search and sorting the incoming information. According to Pereira using the internet can reduce these costs, as occurs when depending on e-commerce, for example e-commerce may lead to lower prices and less variation between prices quoted by different sellers [29]. Second, bargaining costs are the costs paid to reach a suitable agreement with the other party in the transaction, and then signing an appropriate contract. Third, policing and enforcement costs: the costs of making sure the other party are committed to the terms of the contract, and taking appropriate action if they are not. Furthermore, Jaffee suggested that there are six different types of transaction costs; search costs, screen costs, bargaining costs, transfer costs, monitoring costs and enforcement costs [30],

\subsection{Minimizing transaction costs}

The basic idea is "zero transaction costs is a fiction" [2] , so firms must find ways to minimize transaction costs as much as possible to create a competitive advantage, so many researchers, such as [31] [11] investigate how firms decrease transaction costs.

- Trustworthiness reduces transaction costs and is correlated with greater information sharing in supplier-buyer relationships and may be an important source of competitive advantage.

- Reduce the effect of environmental uncertainty and high inter firm asset specificity because of the negative effect on transaction costs and the difficulties they cause.

- Repeated transactions with a small set of suppliers.

- Economies of scale and scope in transactions with a small supplier group (a high volume of exchange between transactors.

- Extensive inter firm information sharing, which reduces asymmetric information.

- The use of non-contractual, self-enforcing safeguards (i.e. goodwill, trust) which is effective for an indefinite time horizon (as opposed to contracts which are effective for a finite time horizon).

\section{Conclusion}

Transaction costs are costs which arise because of the company's activities in the market.

Transaction costs are (fees, commission and taxes) paid by the firm to provide a service or produce a good. Transaction costs are paid to: external parties because of the firm's inability to carry out the operation by itself, in which case these are called (external transaction costs, i.e. market transaction costs). Internal transaction costs include production costs (A-Z). The firm must make a comparison between internal and external transaction costs and choose the lowest cost which enables it to 
increase profits. That means companies have to take into consideration the opportunity costs of each transaction and work hard to reduce transaction costs to a minimum to achieve more profits and competitive advantage.

\section{References}

[1] Brouthers, K.D., 2002. Institutional, cultural and transaction cost influences on entry mode choice and performance. Journal of international business studies, 33(2), pp.203-221.

[2] Coase, R.H., 1937. The nature of the firm. economica, 4(16), pp.386-405.

[3] Williamson, O.E., 1985. The economic institutions of capitalism: Firms, markets, relational contracting (Vol. 866). New York: Free Press.

[4]Coase, R.H., 1988. The nature of the firm: origin. Journal of law, economics, \& organization, 4(1), pp.3-17.

[5]Allen, D.W., 1999. Transaction costs. Encyclopedia of law and economics.

[6] Kissell, R., Glantz, M. and Malamut, R., 2003. Optimal trading strategies: quantitative approaches for managing market impact and trading risk. PublicAffairs.

[7]Williamson, O., 2007. Transaction Cost Economics: An Introduction. Economics Discussion Papers, No 2007-3. Online verfügbar (05.11. 2009): http://www. economics-ejournal. org/economics/discussionpapers/2007-3.

[8] David, R.J. and Han, S.K., 2004. A systematic assessment of the empirical support for transaction cost economics. Strategic management journal, 25(1), pp.39-58.

[9] Macher, J.T. and Richman, B.D., 2008. Transaction cost economics: An assessment of empirical research in the social sciences. Business and Politics, 10(1), pp.1-63.

[10] Brouthers, K.D., Brouthers, L.E. and Werner, S., 2003. Transaction cost-enhanced entry mode choices and firm performance. Strategic Management Journal, 24(12), pp.12391248.

[11] Dyer, J.H. and Chu, W., 2003. The role of trustworthiness in reducing transaction costs and improving performance: Empirical evidence from the United States, Japan, and Korea. Organization science, 14(1), pp.57-68.

[12] Bremen, P., Oehmen, J., Alard, R. and Schönsleben, P., 2010. Transaction costs in global supply chains of manufacturing companies. Journal of Systemics, Cybernetics \& Informatics, 8, pp.19-25.

[13] Hardt, L., 2009. The history of transaction cost economics and its recent developments.

[14] Williamson, O.E., 2008. Outsourcing: Transaction cost economics and supply chain management. Journal of supply chain management, 44(2), pp.5-16.

[15] Commons, J.R., 1934. Institutional economics: Its place in political economy. Macmillan. 
[16] Thompson, J.D., 1967. Organizations in action: Social science bases of administrative theory. Transaction publishers.

[17] Gray, A.W. and Boehlje, M.D., 2005. Risk sharing and transactions costs in producerprocessor supply chains.

[18] Williamson, O.E., 1975. Markets and hierarchies: antitrust analysis and implications. New York: The Free Pres.

[19]Alston, L.J. and Gillespie, W., 1989. Resource coordination and transaction costs: A framework for analyzing the firm/market boundary. Journal of Economic Behavior \& Organization, 11(2), pp.191-212.

[20] Gigerenzer, G. and Goldstein, D.G., 1996. Reasoning the fast and frugal way: models of bounded rationality. Psychological review, 103(4), p.650.

[21] Williamson, O.E., 1979. Transaction-cost economics: the governance of contractual relations. The journal of Law and Economics, 22(2), pp.233-261.

[22]Anderson, E. and Gatignon, H., 1986. Modes of foreign entry: A transaction cost analysis and propositions. Journal of international business studies, 17(3), pp.1-26

[23] Williamson, O.E., 1981. The economics of organization: The transaction cost approach. American journal of sociology, 87(3), pp.548-577.

[24]Aubert, B.A. and Weber, R., 2001. Transaction Cost Theory, the Resource-Based View, and Information Technology Sourcing Decisions: A Re-Examination of Lacity et Al." $\mathrm{s}$ Findings. Cahier du GReSI no, 1(08).

[25] Brouthers, K.D. and Hennart, J.F., 2007. Boundaries of the firm: Insights from international entry mode research. Journal of management, 33(3), pp.395-425.

[26]Kantarelis, D., 2007. Theories of the firm Inderscience Genève Switzerland ISBN 0-90777634-5. ISBN: 0-907776-35-3.

[27] Dahlman, C.J., 1979. The problem of externality. The journal of law and economics, 22(1), pp.141-162.

[28] Smith, G.E., Venkatraman, M.P. and Dholakia, R.R., 1999. Diagnosing the search cost effect: Waiting time and the moderating impact of prior category knowledge. Journal of Economic Psychology, 20(3), pp.285-314.

[29] Pereira, P., 2005. Do lower search costs reduce prices and price dispersion?. Information Economics and Policy, 17(1), pp.61-72.

[30] Jaffee, S., 1995. Transaction costs, risk and the organization of private sector food commodity systems. Marketing Africas High-Value Foods: Comparative Experiences of an Emergent Private Sector. Dubuque. Kendall/Hunt Publishing Company, pp.21-62. 
International Journal of Engineering and Management Sciences (IJEMS) Vol. 2. (2017). No. 3.

DOI: 10.21791/IJEMS.2017.3.13.

[31] Dyer, J.H., 1997. Effective interfirm collaboration: how firms minimize transaction costs and maximize transaction value. Strategic management journal, pp.535-556. 